
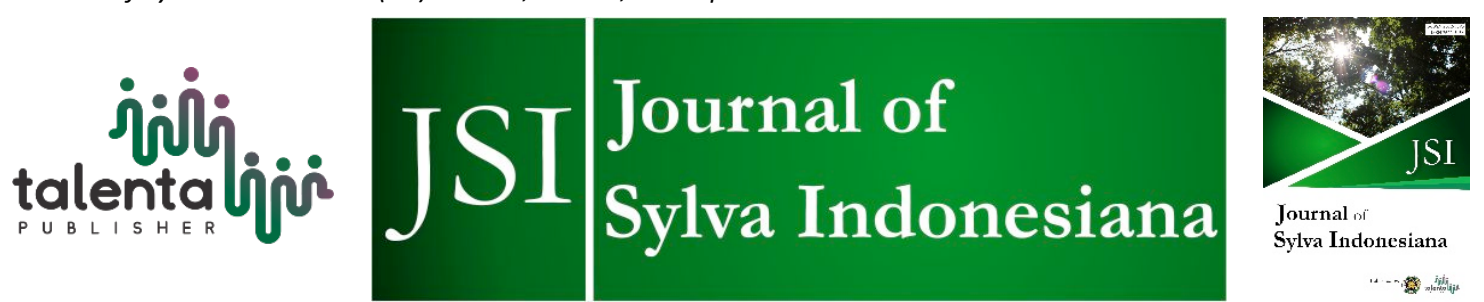

\title{
Suitability of Teak Log Quality from Gunung Kidul and Bantul Yogyakarta Community Forest for Export Meubel Purpose
}

\author{
Sushardi ${ }^{1 *}$, Tibertius Agus Prayitno ${ }^{2}$, Yustinus Suranto ${ }^{2}$, and Ganis \\ Lukmandaru ${ }^{2}$ \\ ${ }^{I}$ Faculty of Forestry, Institut Pertanian STIPER Yogyakarta, Indonesia \\ ${ }^{2}$ Faculty of Forestry, Universitas Gadjah Mada Yogyakarta, Indonesia
}

\begin{abstract}
Natural defect or poor log quality are common in community teak forests. Furniture manufacturers typically use these $\log$ types for export purposes. The aim of this study is to determine the effect of community teak forest location and teak stand age affect on teak wood quality. Three teak forest locations were Bantul and two locations in Gunung Kidul. The teak stand age class namely 6,8 , and 10 years old. The data was analyzed using SPSS 20.0 with Tukey test. The result showed that brittleness defect, sapwood defect, and different wooden knot defects were significant in all locations, while log straightness defect was found only in Dlingo. Similarly, all teak stand age (6, 8, and 10 years old) also produced the same defects such as brittleness defect, sapwood defect, and wood knot defect, while the straightness defect at the age of 10 years old was different from to other two teak stand age (6 and 8-year-old). Average teak log defects were straightness defect $1.87-3.53 \%$, brittleness defect $1.19-6.21 \%$, sapwood defect $1.49-4.82 \mathrm{~cm}$, and wood knot defect 5.10-11.46 cm. However, the teak log quality still met the SNI 7534.2-2010 and 7535.2-2010 as raw material for exporting furniture.
\end{abstract}

Keyword: Brittleness Defects, Furniture Export, Sapwood Defects, Straightness Defects, Teak Community Forest, Wood Knot Defects, Wood Quality

Received 10 June 2021 | Revised 5 July 2021 | Accepted 12 July 2021

\section{Introduction}

A community forest is one form of forest management on property developed by the government [1]-[3]. Community forest teak wood is increasingly sought after by the processing industry, has even begun to occupy a significant portion of the wood market, both for domestic use and export [4]-[5]. Teak wood community forests, on the other hand, are harvested the wood at a young age, with a small diameter, poor quality, and a lot of potential wood waste, making them less desirable and having low market competitiveness [6]. The furniture industry

*Corresponding author at: Faculty of Forestry, Institut Pertanian STIPER Yogyakarta, Indonesia E-mail address: sushardi@instiperjogja.ac.id 
in Indonesia already uses about $80 \%$ of its raw materials from teak wood community forest, where the tree has been cut down at a young age [4],[7]-[9]. Some industries in Yogyakarta, Klaten, and the neighboring regions gather teak wood from a community forest that is 6 to 10 years old. Therefore, it's important to be aware to the distribution of wood quality and the age of the teak community forest. The distribution of quality and age of wood can be used to classify the quality of teak wood forest people, allowing the industry to select high-quality wood based on its origin and age [10]. To promote the export quality furniture sector, knowing the quality of wood based on defects in wood logs may also be used to distribute wood quality.

High-quality teak wood community forests are produced by good planting that generate highquality wood [12]. Maintenance treatments, such as fertilizer, cleaning of the bottom plants, looting, trimming, and pests or disease prevention, have a significant impact on plant growth. Teak from the community forest is commonly utilized in furniture and handicrafts [12]-[13]. The price of products made from the basic materials of the teak community forest is considered expensive [10],[14]. Good quality teak plantations in community forests are characterized by the absence of natural defects [11],[14]. Straightness, brittleness defects, sapwood defects, wood knot defects, liver rot, and other, are type of natural defects that commonly found in teak from community forest [15]-[16]. The quality of logs as raw materials for export furniture is determined by defects in straightness, brittleness, sapwood defects, and wood knot defects [8],[15]-[16]. It is very important to classify quality teak wood community forest based on straightness defects, brittleness defects, sapwood defects, and wood knot defect in various locations [17]. The objectives of this research is to determine the effect of growth location and the plant age on the straightness defects, brittleness defects, sapwood defects, and wood knot defects in teak wood log planted by community forest in Gunung kidul and Bantul.

\section{Methods}

The research was conducted in certified teak community forest in three different locations, namely: Margo Mulyo in Pringsurat Village District Nglipar Gunungkidul, Ngudi Lestari in Dengok Village Playen Gunungkidul District, and JASEMA (Jati Sengon Mahogany) in Terong Dlingo Bantul Village. According to the selection results in the field, the selected trees aged are 6,8 , and 10 years with healthy and straight. Only three trees used for the replication. The trees that are cut down are representative of the height and diameter distribution in each plot. After that, the trunk is separated and the timber quality is classified [8]-[9]. Calculation of straightness defects, brittleness defects, sapwood defects, and the knot defect of teak wood logs based on quality determination and testing methods according to Indonesian National Standard (SNI) 7534.2:2010 and SNI 7535.2:2010 [16],[18]. The influence of planting site and different ages was investigated using univariate variant analysis (ANOVA) and the Tukey test in SPSS 20.0. software [9]. 


\section{Results and Discussion}

\subsection{Straightness Defects (\%)}

The results revealed that the average quality of forest logs with defects in Dlingo's area differs significantly from Nglipar and Playen (Table 1). The Dlingo has the lowest average value those were $1.87 \%$, while Playen and Nglipar have $3.34 \%$ and $3.53 \%$, respectively (Figure 1). Dlingo has a lower straightness defect than other location due to effective management practices. Regular maintenance, particularly pruning, results in a straighter log. Defects in community forest $\operatorname{logs}$ can be reduced by improving plant management, resulting in higher-quality teak wood for furniture raw materials [8],[15],[19]. The types and quantities of defects need to be measured to know the potential for quality degradation due to natural defects produced. Log from Nglipar have diameter average of $21.85 \mathrm{~cm}$. Nglipar wood is classed as medium round wood/KBS (A.II) with a diameter of 20.0-29.9 cm, according to SNI 7535.1-2010. It is classified as class I by the quality class, with a straightness defect of $12 \%$ length $(6 \mathrm{~cm})$. The wood from Playen has a $20.49 \mathrm{~cm}$ average diameter, while wood from Dlingo has a $22.89 \mathrm{~cm}$ average diameter. Both belong to the third class and had one piece less than $5 \%$ length $(\leq 12$ $\mathrm{cm})$ [18]. Defects in the straightness of community forest teak in Nglipar meet the requirements of SNI 7535.1-2010 and SNI 7535.2:2010 [16]. Thus teak wood from Nglipar is suitable as raw materials for export furniture.

The average value quality of $\log$ straightness defects at the age of 6,8 , and 10 years does not significant differently (Table 2). The average values of straightness defects at age 6,8,10 were 2.86, 2.93, and $2.95 \%$ (Figure 2). Statistically, the straightness log defects at the age of 6,8 , and 10 years have almost the same value. This is because the trend of stem growth at the age of 6,8 , and 10 years tends to be the same. The quality of round teak wood can determine the direction of further use [8]. Various types of defects will reduce the quality and selling value of the wood, minimal defects will result in higher quality and worthy teak wood. Knowing the type and number of defects logs, can be used as a reference for the community in teak forest management [8]. The results of this study indicate that the quality of 6-year-old logs with an average diameter of $16.51 \mathrm{~cm}$ is classified in the quality of small $\operatorname{logs} / \mathrm{KBK}$ (AI) and the third quality class $(\mathrm{T})$ with straightness defects of two lengths of $3 \%$ according to [18]. The 8 -yearold logs with an average diameter of $22.47 \mathrm{~cm}$ and 10-year-old logs with an average diameter of $26.46 \mathrm{~cm}$ were classified into medium $\log$ quality/KBS (A.II) and second quality class (D) with straightness defects onepiece length $3 \%(\leq 8 \mathrm{~cm})$ according [18]. Teak straightness defects at the age of 8 and 10 years meet the requirements of SNI 7534.2:2010 and SNI 7535.2:2010. Thus, teak wood from forest communities at the age of 8 and 10 years can be used as raw material for furniture exports. 
Table 1 Average Quality of Community Forest Teak Logs In Different Locations

\begin{tabular}{clccc}
\hline No & \multicolumn{1}{c}{ Parameters } & Nglipar & Playen & Dlingo \\
\hline 1 & Straightness Defect (\%) & $3.53 \mathrm{a}$ & $3.34 \mathrm{a}$ & $1.87 \mathrm{~b}$ \\
2 & Brittleness Defect (\%) & $4.76 \mathrm{~d}$ & $3.96 \mathrm{e}$ & $2.05 \mathrm{f}$ \\
3 & Sapwood Defect $(\mathrm{cm})$ & $4.82 \mathrm{k}$ & $2.98 \mathrm{1}$ & $1.49 \mathrm{~m}$ \\
4 & Wood Knot Defect $(\mathrm{cm})$ & $11.46 \mathrm{x}$ & $8.45 \mathrm{y}$ & $5.10 \mathrm{z}$ \\
\hline
\end{tabular}

Note: Numbers followed by the same letter in each factor and parameter indicate no significant difference $(\mathrm{P}<0.01)$.

\subsection{Brittleness Defect (\%)}

The results on brittleness defects from three locations showed not significant different value (Table 1). The average value of brittleness defects from Dlingo, Playen and Nglipar were 2.05 $\%, 3.96 \%, 4.76 \%$ (Figure 1). Due to community pruning efforts, the number of brittleness defects in logs obtained from Dlingo is reduced. Brittleness defects are brittle wood deformities that can be found in the bottom of the wood. Teak defects can reduce by proper plant maintenance [8],[18]-[19]. Teak plants growth qualities can be influenced by silviculture practices such as spacing, fertilization, and pruning. It'll have an effect on the quality of the timber that's created [8],[20]-[21]. Based on SNI 7535.1-2010 log from Nglipar, Player and Dlingo classified into wood medium round/ KBS (A.II) with a diameter of 20.0-29.9 cm first quality class $(\mathrm{P})$ with brittleness defects $\leq 5 \%$ diameter [18]. Brittleness deffects of log from three locations meet the requirements of [16] and [18] and also suitable to be used as raw materials for export furniture. The average value of brittleness defects at the age of 6,8 , and 10 years showed significant diffrent value (Table 2). The average value of brittleness defects of aged 6,8 and 10 were $2.70 \%, 3.62 \%$, and $4.45 \%$ (Figure 2). Wood logs at aged 6 years listed into small round wood/KBK (A.I) with and including the first quality class (P) with defects of $\leq$ $5 \%$ diameter [18]. Wood logs at aged 8 and 10 years classifiend into medium round wood / KBS (A.II) with a diameter of 20.0-29.9 cm, including the second quality class (D) with community forest $\leq 5 \%$ diameter according to [18]. Brittleness defects of teak from aged 6,8 , and 10 meet the requirements SNI 7534.2:2010 and. Thus this teak can be used as raw materials for export furniture.

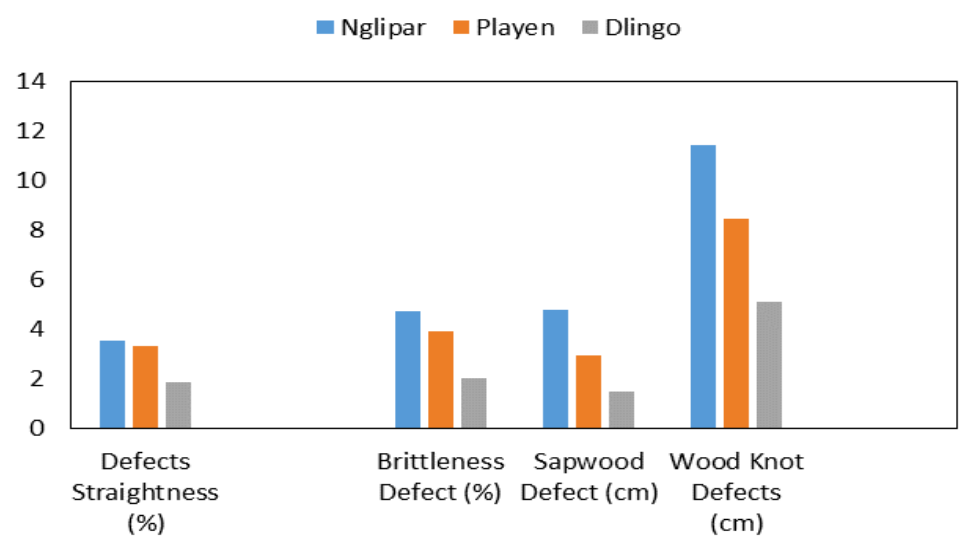

Figure 1 Log Deffect of Teak from Different Locations 


\subsection{Sapwood Defects (cm)}

The results on sapwood defects of Nglipar, Playen and Dlingo show significant different value (Table 1). The average value of defects from Dlingo, Playen and Nglipar were $1.49 \mathrm{~cm}, 2.98$ $\mathrm{cm}$, and $4.82 \mathrm{~cm}$ (Figure 1). Sapwood defect is a defect of the wooden part between the bark and the heartwood, generally lighter in color than the sapwood. The defect of log from Dlingo location is lower because of intensive silvicultere practice compared to other locations. Regular maintenance especially for pruning, will produce a straight teak log and low sapwood defects [8],[15],[19]. Activities such as spacing, fertilization, and pruning of branches can affect the growth properties of teak and will impact on the quality of wood [8],[20]-[21]. The community forest would be able to produce good quality wood with few natural defects if extensive and good management operations are carried out [8],[20]. Log teak from Dlingo classified into wood medium round/ KBS (A.II) and first quality class (P) with sapwood defects $\leq 2 \mathrm{~cm}$. Log from Playen classified into second quality class (D) with sapwood defects $\leq 3 \mathrm{~cm}$ and Nglipar classified into third quality class (T) there is no requirement [18]. Sapwood defects from Nglipar, meet the requirements of [16] and [18]. Thus teak wood from Nglipar is suitable as raw materials for export furniture.

Average value quality sapwood defects at the age of 6,8 , and 10 years show not significant different value (Table 2). The average of aged 6, 8, 10 were $3.01 \mathrm{~cm}, 3.06 \mathrm{~cm}$, and $3.22 \mathrm{~cm}$ (Figure 2). Wood defects are abnormalities found in wood that can impact the quality and composition of the material [22]-[23]. The requirements of wood for a specific function are determined by the qualities of the wood. For example, the wood used in furniture must have a high strength class. Log teak at aged 6 years classified into small round wood/ KBK (A.I) and second quality class (D) [18]. Teak logs at the aged 8 and 10 classified into the quality of medium round wood/ KBS (A.II) and third quality class (T) with sapwood defects no requirements [18].

\subsection{Wood Knot Defects (cm)}

The average of wood knot defects from Nglipar, Playen, and Dlingo showed significant differen value (Table 1). The average value of knot defects in Dlingo, Playen and Nglipar were $5.10 \mathrm{~cm}$, $8.45 \mathrm{~cm}$, and $11.46 \mathrm{~cm}$ (Figure 1). Knot defects are branches or scuff marks on the wood body. The Dlingo area has less knot wood defects than other locations. This is due to the Jasema Dlingo Community of Bantul's continuous tree maintenance, particularly pruning efforts, which result in straight-trunk wood and clear of knot defects [4],[20]. 
Table 2 Wood Logs Quality of Community Forest Based on The Ages

\begin{tabular}{clccc}
\hline \multirow{2}{*}{ No } & \multicolumn{1}{c}{ Parameters } & \multicolumn{3}{c}{ Age } \\
\cline { 3 - 5 } & & $2.86 \mathrm{p}$ & $2.93 \mathrm{p}$ & $2.95 \mathrm{p}$ \\
\hline 1 & Straightness Defect (\%) & $2.70 \mathrm{t}$ & $3.62 \mathrm{u}$ & $4.45 \mathrm{~s}$ \\
2 & Brittleness Defect (\%) & $3.01 \mathrm{k}$ & $3.06 \mathrm{k}$ & $3.22 \mathrm{k}$ \\
3 & Sapwood Defect (cm) & $8.14 \mathrm{x}$ & $8.29 \mathrm{x}$ & $8.59 \mathrm{x}$ \\
4 & Wood Knot Defects (cm) & Coct
\end{tabular}

NB. Numbers followed by the same letter in each factor and parameter indicate no significant difference $(\mathrm{P}<0.01)$.

Teak wood in community forests planted together in rice fields, gardens, or fields by residents. This causes the quality or variation of its nature is not widely known. The heterogeneous condition of community forest also affects the quality of the wood produced [9],[24]. The degree of relationship between the wood properties and the specific wood use requirements is reflected in wood quality. The suitable wood properties and the requirements, the higher the quality of the wood. As a result, the raw material used for the furniture industry must also be clear of defects in order for resulting the high quality of end product. Based on [18], teak logs from Dlingo and Playen classified into medium round /KBS (A.II) with knot defects are 3 pieces $/ \mathrm{m}$ and the diameter of $\leq 10 \mathrm{~cm}$. Log from Nglipar classified in the third quality class (T) with nemuber of knot defect 4 pieces $/ \mathrm{m}$. Wood knot defects from Playen and Dlingo meet the requirements of [16] and [18]. Thus this teak wood can be used as raw materials for export furniture.

The average value of knot defects at age 6, 8, and 10 was not significant different (Table 2). The average value of knot defects for $6,8,10$ years is $8.14 \mathrm{~cm}, 8.29 \mathrm{~cm}$, and $8.59 \mathrm{~cm}$ (Figure 2). Teak knot defects at the age of 6, 8, and 10 still meet the requirements of SNI 7534.2:2010 and SNI 7535.2:2010. Based on [18], the log of 6 years age classified into small round wood / KBK (A.I) and second quality class (D) with knot defects three pieces/meter and diameter of $\leq 10 \mathrm{~cm}$ [18]. Teak log aged 8 and 10 classified into medium round wood/KBS (A.II) and second quality class (D) with number of knot are three pieces/meter and diameter of $\leq 10 \mathrm{~cm}$ [18]. Teak straightness defects at the age of 8 and 10 years meet the requirements SNI 7534.2:2010 and SNI 7535.2:2010 [15],[25] and suitable as raw materials for furniture export. 


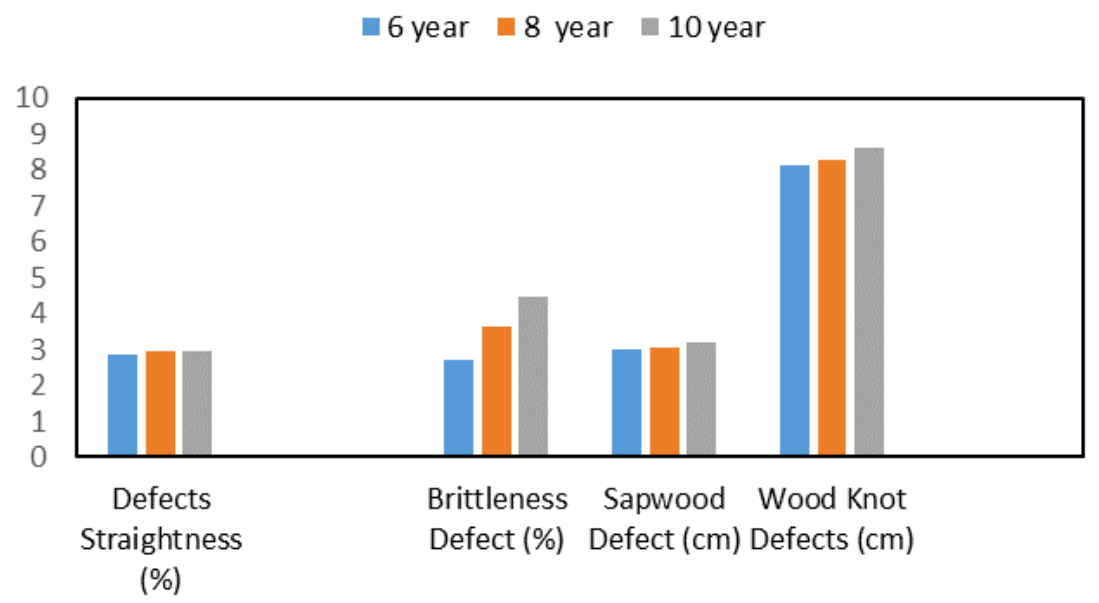

Figure 2 Log Teak Quality Based on Age

\section{Conclussion}

The Nglipar, Playen, and Dlingo community forests produce quality logs with different proportions of brittleness defects, sapwood defects, and wood knot defects. The wood from Dlingo has a different proportion of straightness defects compared to other locations. Based on the age, trees aged 6,8 , and 10 years produced quality logs with significant different brittleness, sapwood defects, and wood knot defects, while straightness defects at 10 years showed different results from those aged 6 and 8. Teak wood from Nglipar, Playen, and Dlingo aged 6, 8, and 10 years meets the requirements of SNI 7534.2:2010 and SNI 7535.2:2010 so that it can be used as raw materials for furniture export.

\section{Acknowledgment}

We thank the Head of the Department of Forestry and Plantation Yogyakarta Province for for research permission in the People's Forest of Gunung Kidul regency and Bantul regency. We would like to thank the Margo Mulyo Certified People's Forest Farmer Group of Pringsurat Village of Nglipar Gunungkidul Subdistrict, Ngudi Lestari in Dengok Village, Playen Gunungkidul Subdistrict, JASEMA (Jati Sengon Mahoni) of Dlingo Bantul Eggplant Village, who gave research permission on site. We are grateful to Research and Community Service Institute, Institut Pertanian "STIPER" Yogyakarta, who gave us the opportunity to conduct this research.

\section{REFERENCES}

[1] Hakim, L, R. Widyorini, W. D. Nugroho, and T. A. Prayitno, "Anatomical, chemical, and mechanical properties of fibrovascular bundles of Salacca (Snake Fruit) frond," BioResources, vol. 14, no. 4, pp. 7943-7957. 2019. doi: 10.15376/biores.14.4.7943-7957.

[2] Pratiwi, T. K. Karmanah, and R. Gusmarianti, "Inventarisasi Hama Dan Penyakit Tanaman Jati Unggul Nusantara Di Kebun Percobaan Cogrek Bogor," J. Sains Nat., vol. 2, no. 2, p. 123. 2017, doi: 10.31938/jsn.v2i2.42. 
[3] Wattimena, C. M. F. Latumahina, and N. K. Kartikawati, "Inventory of insects and levels of damages on teak (Tectona grandis LINN . F) at forest plants Hila State District, Maluku Dist," vol. 14, no. 1, pp. 1-8. 2020.

[4] Pramono, A.A.M.A. Fauzi, N. Widyani, I. Heriansyah, and J. M. Roshetko, Panduan Pengelolaan Hutan Jati Rakyat. 2010.

[5] Wali, M. and E. S. Ningkeula, "Tingkat Kerusakan Batang Akibat Serangan Hama Pada Tegakan Jati," Agrikan J. Agribisnis Perikan., vol. 12, no. 2, pp. 272-278. 2019, doi: 10.29239/j.agrikan.12.2.272-278.

[6] Prayitno, T. A. et al., "Sifat Finishing Kayu Jati Setelah Perlakuan Panas," Pros. Semin. Nas. Masy. Peneliti Kayu Indones. Xvi, pp. 75-82. 2013.

[7] Marsoem, S. N., V. Prasetyo, and J. Sulistyo, "Studi Mutu Kayu Jati di Hutan Rakyat Gunungkidul III. Sifat Fisika Kayu," J. Ilmu Kehutan., vol. 8, no. 2, pp. 75-88. 2016, doi: 10.22146/jik.10162.

[8] Ardhiansyah, A. G. E. Tavita, and I. A. M, "Identifikasi jenis cacat kayu bulat jati (Tectona grandis Linn. F.) pada areal pemanenan di KPH Jember," J. Hutan Lestari, vol. 7, no. 1, pp. 525-531. 2019, doi: 10.26418/jhl.v7i1.32377.

[9] Lukmandaru, G., V. Prasetyo, J. Sulistyo, and S. N. Marsoem, "Sifat pertumbuhan kayu jati dari hutan rakyat gunungkidul," no. June 2018, 2010.

[10] Zhao, Q., S. Yu, F. Zhao, L. Tian, and Z. Zhao, "Comparison of machine learning algorithms for forest parameter estimations and application for forest quality assessments," For. Ecol. Manage., vol. 434, no. December 2018, pp. 224-234. 2019. doi: 10.1016/j.foreco.2018.12.019.

[11] Ioannidou, D., R. Pommier, G. Habert, and G. Sonnemann, "Evaluating the risks in the construction wood product system through a criticality assessment framework," Resour. Conserv. Recycl., vol. 146, no. December 2018, pp. 68-76. 2019. doi: 10.1016/j.resconrec.2019.03.021.

[12] Wahyudi, I. D. Kristia Dinata Sinaga, and L. Binti Jasni, "Pengaruh Jarak Tanam Terhadap Pertumbuhan Pohon dan Beberapa Sifat Fisis-Mekanis Kayu Jati Cepat Tumbuh (Spacing Effect on Tree Growth and Several Physical-Mechanical Properties of Faster-Grown Teak Wood)," J. Ilmu Pertan. Indones. (JIPI), Desember, vol. 19, no. 3, pp. 204-210. 2014.

[13] Duryat, D. and R. Hilmanto, "Strategi Pengembangan Hutan Rakyat di Desa Bandar dalam Kecamatan Sidomulyo Kabupaten Lampung Selatan," J. Sylva Lestari, vol. 7, no. 1, pp. 110-117. 2019, Available: http://repository.lppm.unila.ac.id/21775/.

[14] Purnomo, H. P. Guizol, and D. R. Muhtaman, "Governing the teak furniture business: A global value chain system dynamic modelling approach," Environ. Model. Softw., vol. 24, no. 12, pp. 1391-1401. 2009, doi: 10.1016/j.envsoft.2008.04.012.

[15] BSN, Kayu gergajian jenis jati - Cara uji, 2010.

[16] BSN, Kayu gergajian - Bagian 3: Pemeriksaan, 2011.

[17] Nambiar, E. K. S. "Re-imagining forestry and wood business: Pathways to rural development, poverty alleviation and climate change mitigation in the tropics," For. Ecol. Manage., vol. 448, no. April, pp. 160-173. 2019. doi: 10.1016/j. foreco.2019.06.014.

[18] BSN, "Kayu bundar jenis jati - Bagian 1: Klasifikasi , persyaratan dan penandaan," Indones. Standar Nasional, Badan Stand. Nas. Indones., 2010.

[19] Adinugraha, H. A. and M. A. Fauzi, "Pertumbuhan Klon Jati Asal Cepu dan Madiun Umur 10 Tahun pada Lahan Berbatu di Gunung Kidul," J. Hutan Trop., vol. 3, no. 3, pp. 253-259. 2016, Available: https://ppjp.ulm.ac.id/ journal/index.php/ jht/ article/ view/2277.

[20] Hendra Supriatna, A. and N. Wijayanto, "Pertumbuhan Tanaman Pokok Jati (Tectona grandis Linn F.) pada Hutan Rakyat di Kecamatan Conggeang, Kabupaten Sumedang Main," vol. 02, no. 03, pp. 130-135. 2011.

[21] Widiatmaka, A. Mediranto, and H. Widjaja, "Karakteristik, Klasifikasi Tanah, Dan Pertumbuhan Tanaman Jati (Tectona grandis Linn f.) Var. Unggul Nusantara Di Ciampea, Kabupaten Bogor," J. Nat. Resour. Environ. Manag., vol. 5, no. 1, pp. 87-87. 2015, doi: 10.29244/jps1.5.1.87.

[22] Kumi, J. A. B. Kyereh, M. Ansong, and W. Asante, "Influence of management practices on stand biomass, carbon stocks and soil nutrient variability of teak 
plantations in a dry semi-deciduous forest in Ghana," Trees, For. People, vol. 3, no. September 2020, p. 100049. 2021. doi: 10.1016/j.tfp.2020.100049.

[23] Chayaporn, P. N. Sasaki, M. Venkatappa, and I. Abe, "Assessment of the overall carbon storage in a teak plantation in Kanchanaburi province, Thailand Implications for carbon-based incentives," Clean. Environ. Syst., vol. 2, no. March, p. 100023. 2021. doi: 10.1016/j.cesys.2021.100023.

[24] J. Sulistyo, G. Lukmandaru, V. E. Prasetyo, and S. N. Marsoem, "Karakteristik biomasa komponen pohon jati dari hutan rakyat di gunung Kidul," Hutan Kerakyatan Mengatasi Perubahan Iklim; Pros. Semin. Nas. Dies ke-46 Fak. Kehutan. UGM 2009, pp. 124-130. 2010.

[25] BSN, Kayu bundar daun lebar - Bagian 1: Klasifikasi, persyaratan dan penandaan, 2010. 